\title{
Elution of Acid Phosphatase from the Cell Surface of Saccharomyces mellis by Potassium Chloride
}

\author{
RALPH WEIMBERG' ${ }^{1}$ AND WILLIAM L. ORTON \\ Pioneering Laboratory for Microbiological Chemistry, Northern Regional Research Laboratory, \\ U.S. Department of Agriculture, Peoria, Illinois
}

Received for publication 11 February 1965

\begin{abstract}
Weimberg, Ralph (Northern Regional Research Laboratory, Peoria, Ill.), AND William L. Orton. Elution of acid phosphatase from the cell surface of Saccharomyces mellis by potassium chloride. J. Bacteriol. 90:82-94. 1965.-Acid phosphatase of Saccharomyces mellis may be eluted from intact resting cells by $0.5 \mathrm{M} \mathrm{KCl}$ or other salts. However, the enzyme is not eluted at higher salt concentrations of about $2 \mathrm{~m}$ unless a thiol, such as $\beta$-mercaptoethanol, is included in the reaction mixture. These treatments do not significantly affect viability of the cells. Neutral compounds like sorbitol or sucrose cannot substitute for ionic compounds in eluting the enzyme from resting cells. Furthermore, the neutral compounds are also inadequate for stabilizing the protoplast structure. It is suggested that the enzyme is held on the cell surface by a combination of electrostatic forces and disulfide bonds. Thiol alone dissociates protein and carbohydrate from the cell surface, but the eluate has no acid phosphatase activity. Salts also remove protein and carbohydrate from the cell surface, but the amount of protein removed is considerably less than that dissociated by thiol. A concentration of $0.5 \mathrm{~m} \mathrm{KCl}$ elutes more protein than does a $2 \mathrm{~m}$ concentration, and enzymatic activity is present only in the $0.5 \mathrm{M} \mathrm{KCl}$ eluate. The carbohydrate eluted by either reagent has been identified as a mannan. Conditions for eluting acid phosphatase from acetonedried cells of $S$. mellis are essentially the same as those for resting cells. Significantly, though, thiol is required at all salt concentrations to dissociate the enzyme. Pretreatment of the cells with thiol, followed by $\mathrm{KCl}$, elutes acid phosphatase, whereas the reverse procedure does not. Acid phosphatase is excreted by growing cells of $S$. mellis into growth media if the medium contains $0.25 \mathrm{M} \mathrm{KCl}$. The total yield of enzymatic activity may be 8 to 10 times greater than is usually present on derepressed cells grown in a salt-free medium. The enzyme can be precipitated from the culture fluid with acetone. The acetone-precipitated fraction contains mannan and protein in a ratio of 12:1 by weight. Partial purification of the enzyme by calcium phosphate gel and elution resulted in an enzyme fraction in which the specific activity on the basis of protein increased 12-fold, and the carbohydrate-protein ratio was reduced to 1:1.
\end{abstract}

Protoplasts have been obtained from cells of Saccharomyces mellis in the maximal stationary phase of growth by digesting the cell walls with an extract from the gut of Helix pomatia (Weimberg and Orton, 1964). However, digestion of the walls occurred only if a thiol, like $\beta$-mercaptoethanol, was included in the reaction mixture. Also, a rather high concentration of $\mathrm{KCl}(2 \mathrm{M})$ was needed in the medium to stabilize the protoplast structure, in comparison with the amount found satisfactory for stabilizing protoplasts of S. cerevisiae, Candida utilis, and other yeasts (McLellan and Lampen, 1963; Svihla, Schlenk, and Dainko, 1961; Holter and Ottolenghi, 1960).

Under these conditions, acid phosphatase was

1 Present address: U.S. Salinity Laboratory, P.O. Box 672, Riverside, Calif. released from cells of $S$. mellis, which indicated an exocellular location for the enzyme. Though release of this enzyme seemed related to protoplast formation, it was noted that acid phosphatase activity was always eluted before the cells became osmotically fragile. At the time, it seemed as if the acid phosphatase was located in a portion of the cell wall that was digested at a faster rate by the enzymes in the crude extract of snail gut than those parts of the wall responsible for rigidity.

This report is concerned with determining the conditions under which the acid phosphatase of S. mellis may be separated from intact cells. Actually, the elution of the enzyme is not necessarily a part of the process of protoplast formation. Elution occurs in the absence of snail-gut 
extract, but in a reaction mixture containing all the other reagents that are used for protoplast formation and stabilization. Although this treatment removes the exocellular enzyme from cells, it does not result in the cells becoming osmotically fragile or in any loss in viability. The removal of several exocellular enzymes from Escherichia coli without spheroplast formation or loss of viability was recently described (Neu and Heppel, 1964). The conditions under which the enzymes were eluted from the bacterial cells are somewhat different from those reported here for $S$. mellis.

\section{Materials and Methods}

The medium for growing $S$. mellis NRRL Y-1053, so that it contains acid phosphatase; the method for preparation of resting-cell suspensions and acetone-dried powders of this organism; and the technique for preparing protoplasts have all been previously described (Weimberg and Orton, 1964). Acid phosphatase activity was determined by measuring the amount of inorganic phosphate formed from pyrophosphate after incubation at $30 \mathrm{C}$ of $0.2 \mathrm{ml}$ of cells or supernatant fluid mixed with $0.2 \mathrm{ml}$ of $1.0 \mathrm{M}$ acetate $(p \mathrm{H} 5.5), 0.05 \mathrm{ml}$ of $0.1 \mathrm{~m}$ sodium pyrophosphate $(p \mathrm{H} 7)$, and $0.15 \mathrm{ml}$ of water. Samples of $0.2 \mathrm{ml}$ were removed at the beginning and after $10 \mathrm{~min}$ of incubation, and were added to $2.0 \mathrm{ml}$ of $10 \%$ trichloroacetic acid to stop the reaction. Particulate material, if any, was removed by centrifugation, and the supernatant fluids were assayed for inorganic phosphate. If necessary, the cells or supernatant fluid should be diluted so that no more than two-thirds of the substrate is hydrolyzed in the 10-min incubation period. Activity is expressed as micromoles of inorganic phosphate formed in $\mathbf{1 0}$ min at $30 \mathrm{C}$ by $1 \mathrm{ml}$ of cells removed from an incubation mixture by centrifugation and suspended in water to the same concentration, or 1 $\mathrm{ml}$ of the incubation-mixture supernatant fluid. The amounts of the various salts, thiols, and other chemicals used had no harmful effect on the acid phosphatase or on the reaction it catalyzes, except in the cases noted. Inorganic phosphate was determined as described by Taussky and Shorr (1953). Protein was measured by use of the FolinCiocalteau reagent (Lowry et al., 1951), and total carbohydrate by use of the anthrone reaction (Hassid and Abraham, 1957) with mannose as the standard. Calcium phosphate gel was prepared as described by Keilin and Hartree (1938). All chemicals were from commercial sources.

\section{Results}

Elution of acid phosphatase from resting cells. The previously described conditions for eluting acid phosphatase from resting cells of $S$. mellis were the same as those for converting the cells into protoplasts, except that it was necessary to include arsenite in the reaction mixture to recover the enzyme in an active form (Weimberg and Orton, 1964). We found that acid phosphatase may be eluted from cells without even digest

TABLE 1. Conditions for eluting acid phosphatase from resting cells of Saccharomyces mellis

\begin{tabular}{|c|c|c|c|c|}
\hline \multirow{3}{*}{ Reaction mixture } & \multicolumn{4}{|c|}{ Activity* } \\
\hline & \multicolumn{2}{|c|}{ In cells } & \multicolumn{2}{|c|}{ In supernatant fluid } \\
\hline & Initial & Final & Initial & Final \\
\hline A. Thiol-treated cells $+\mathrm{KCl}+$ snail extract + arsenite. & 31.5 & 1.5 & 1.5 & 38.0 \\
\hline B. Thiol-treated cells $+\mathrm{KCl}+$ snail extract ........... & 30.0 & 0.5 & 1.5 & 3.5 \\
\hline C. Thiol-treated cells $+\mathbf{K C l}+$ arsenite....... & 31.5 & 41.5 & 1.5 & 1.0 \\
\hline D. Untreated resting cells $+\mathrm{KCl}+\beta$-mercaptoethanol. & 31.5 & 4.0 & 0 & 40.5 \\
\hline E. Untreated resting cells $+\mathrm{KCl} \ldots \ldots$ & 32.0 & 29.5 & 2.0 & 2.2 \\
\hline F. Untreated resting cells $+\beta$-mercaptoethanol & 32.0 & 34.5 & 1.5 & 3.0 \\
\hline
\end{tabular}

* All values are expressed as micromoles of phosphate per 10 min per milliliter. Cells in reaction mixtures A, B, and C were pretreated as follows: $2.5 \mathrm{ml}$ of an aqueous suspension of resting cells of $S$. mellis $(0.4 \mathrm{~g} / \mathrm{ml})$ were added to $2.5 \mathrm{ml}$ of a solution of $0.2 \mathrm{M}$ acetate buffer $(p \mathrm{H} 6.5)$ and $0.02 \mathrm{M} \beta$-mercaptoethanol. After incubation for $2 \mathrm{hr}$ at $30 \mathrm{C}$, the mixture was centrifuged; cells were washed once in water and then suspended in $2.5 \mathrm{ml}$ of water. For reaction mixture $\mathrm{A}$, the following additions were made to 0.4 $\mathrm{ml}$ of the treated cells: $1.0 \mathrm{ml}$ of $4 \mathrm{M} \mathrm{KCl} ; 0.1 \mathrm{ml}$ of $1.0 \mathrm{M}$ acetate buffer $(p \mathrm{H} 6.5) ; 0.4 \mathrm{ml}$ of $0.1 \mathrm{M}$ sodium arsenite $(p \mathrm{H} 6.5) ; 0.1 \mathrm{ml}$ of snail-gut extract. For reaction mixture B, arsenite was omitted, and the volume was brought to $2.0 \mathrm{ml}$ with water. In reaction mixture $\mathrm{C}$, the snail extract was replaced with an equivalent amount of water. For reaction mixtures D, E, and F, $0.4 \mathrm{ml}$ of untreated cells $(0.4 \mathrm{~g} / \mathrm{ml})$ was added to $0.1 \mathrm{ml}$ of $1.0 \mathrm{M}$ acetate $(p \mathrm{H} 6.5)$ and either $1.0 \mathrm{ml}$ of $4 \mathrm{M} \mathrm{KCl}$ or $0.5 \mathrm{ml}$ of $0.1 \mathrm{M} \beta$-mercaptoethanol, or both, and the reaction mixtures were diluted to $2.0 \mathrm{ml}$ with water. All reaction mixtures were incubated at $30 \mathrm{C}$. Initially and after $60 \mathrm{~min}$ of incubation, $0.5 \mathrm{ml}$ was removed from each reaction mixture and centrifuged; the cells were washed once in water and then suspended in $0.5 \mathrm{ml}$ of water. Enzymatic activity of the supernatant fraction and of the washed cells was determined. 
ing the yeast cell wall (Table 1). Furthermore, when the snail-gut extract (the source of the enzymes for breaking down cell walls) was omitted from the reaction mixture, arsenite was no longer needed to protect or stabilize the phosphatase. Acid phosphatase was removed from the cells at a slightly lower rate in the absence of snail extract and arsenite than in their presence. Apparently, enzymatic digestion of the cell wall does have a somewhat stimulatory effect on this phenomenon.

At a concentration of $2 \mathrm{~m} \mathrm{KCl}$, the minimal amount required to stabilize protoplasts of $S$. mellis, both $\mathrm{KCl}$ and $\beta$-mercaptoethanol were required to elute acid phosphatase from cells (Table 1). As salt concentration decreased, however, the requirement for a thiol disappeared,

TABLE 2. Effect of various concentrations of $\mathrm{KCl}$ on the elution of acid phosphatase from intact cells in the presence and absence of $\beta$-mercaptoethanol

\begin{tabular}{|c|c|c|c|c|c|}
\hline \multirow{3}{*}{$\begin{array}{l}\text { Concn } \\
\text { of salt }\end{array}$} & \multirow{3}{*}{$\begin{array}{c}\text { Presence of } \\
\beta \text {-mercaptoethanol }\end{array}$} & \multicolumn{4}{|c|}{ Activity* } \\
\hline & & \multicolumn{2}{|c|}{ In cells } & \multicolumn{2}{|c|}{$\begin{array}{l}\text { In supernatant } \\
\text { fluid }\end{array}$} \\
\hline & & Initial & Final & Initial & Final \\
\hline$M$ & & & & & \\
\hline 0 & + & $\begin{array}{l}34.0 \\
33.0\end{array}$ & $\begin{array}{l}39.4 \\
34.8\end{array}$ & $\begin{array}{l}2.0 \\
1.1\end{array}$ & $\begin{array}{l}2.9 \\
1.5\end{array}$ \\
\hline 0.1 & + & $\begin{array}{l}34.8 \\
33.0\end{array}$ & $\begin{array}{l}26.5 \\
26.1\end{array}$ & $\begin{array}{l}2.2 \\
1.5\end{array}$ & $\begin{array}{r}10.3 \\
3.5\end{array}$ \\
\hline 0.5 & + & $\begin{array}{l}32.3 \\
31.3\end{array}$ & $\begin{array}{r}5.2 \\
11.3\end{array}$ & $\begin{array}{l}2.0 \\
1.9\end{array}$ & $\begin{array}{l}51.0 \\
36.3\end{array}$ \\
\hline 1.0 & + & $\begin{array}{l}32.3 \\
30.6\end{array}$ & $\begin{array}{r}8.5 \\
20.4\end{array}$ & $\begin{array}{l}2.0 \\
1.6\end{array}$ & $\begin{array}{l}44.0 \\
18.2\end{array}$ \\
\hline 1.5 & + & $\begin{array}{l}32.0 \\
31.0\end{array}$ & $\begin{array}{l}18.6 \\
27.5\end{array}$ & $\begin{array}{l}2.0 \\
1.7\end{array}$ & $\begin{array}{r}29.9 \\
2.2\end{array}$ \\
\hline 2.0 & + & $\begin{array}{l}32.0 \\
31.3\end{array}$ & $\begin{array}{l}23.0 \\
26.1\end{array}$ & $\begin{array}{l}2.2 \\
1.7\end{array}$ & $\begin{array}{r}15.3 \\
2.3\end{array}$ \\
\hline
\end{tabular}

* All values are expressed as micromoles of phosphate per 10 min per milliliter. The reaction mixtures contained the following: $1.5 \mathrm{ml}$ of a resting-cell suspension of $S$. mellis $(0.3 \mathrm{~g} / \mathrm{ml})$; $0.1 \mathrm{ml}$ of $1.0 \mathrm{M}$ acetate buffer $(p \mathrm{H} 6.5) ; 0.2 \mathrm{ml}$ of $3 \% \beta$-mercaptoethanol in those reaction mixtures in which it was added; enough $4 \mathrm{~m} \mathrm{KCl}$ to give the concentrations listed in a final volume of $\mathbf{5 . 0}$ $\mathrm{ml}$. Samples of $1.0 \mathrm{ml}$ were removed initially and after $60 \mathrm{~min}$ of incubation at $30 \mathrm{C}$. Cells were removed from these samples by centrifugation and were suspended in the same volume of water. Enzymatic activity of cells and supernatant fractions was determined.
TABLE 3. Elution of acid phosphataseby $\beta$-mercaptoethanol from Saccharomyces mellis cells suspended in $2 \mathrm{M} \mathrm{KCl}$

\begin{tabular}{|c|c|c|c|c|}
\hline \multirow{3}{*}{$\begin{array}{l}\text { Concn of } \\
\beta \text {-mercapto- } \\
\text { ethanol }\end{array}$} & \multicolumn{4}{|c|}{ Activity* } \\
\hline & \multicolumn{2}{|c|}{ In cells } & \multicolumn{2}{|c|}{ In supernatant fluid } \\
\hline & Initial & Final & Initial & Final \\
\hline$\%$ & & & & \\
\hline 0 & 34.5 & 33.0 & 0.7 & 1.0 \\
\hline 0.01 & 35.1 & 32.9 & 0.7 & 1.1 \\
\hline 0.02 & 34.1 & 30.0 & 0.9 & 1.7 \\
\hline 0.05 & 33.4 & 28.2 & 1.0 & 2.6 \\
\hline 0.10 & 33.0 & 23.0 & 1.4 & 7.3 \\
\hline 0.25 & 36.2 & 14.6 & 1.6 & 20.5 \\
\hline 0.5 & 36.2 & 9.1 & 1.0 & 35.1 \\
\hline 1.0 & 35.5 & 8.7 & 1.1 & 33.7 \\
\hline
\end{tabular}

* All values are expressed as micromoles of phosphate per 10 min per milliliter. Each reaction mixture contained $0.5 \mathrm{ml}$ of resting cells of $S$. mellis $(0.4 \mathrm{~g} / \mathrm{ml}), 0.1 \mathrm{ml}$ of $1.0 \mathrm{M}$ acetate buffer $(p \mathrm{H} 6.5), 1.25 \mathrm{ml}$ of $4 \mathrm{M} \mathrm{KCl}$, and sufficient $\beta$ mercaptoethanol to give the concentrations listed in a final volume of $2.5 \mathrm{ml}$. Samples of $1.0 \mathrm{ml}$ were removed from the reaction mixtures initially and after 30 min of incubation at $30 \mathrm{C}$ and centrifuged; the cells were suspended in $1.0 \mathrm{ml}$ of water. Enzymatic activity of cells and supernatant fractions was determined.

though thiol remained stimulatory at all salt concentrations (Table 2). The optimal concentration of $\mathrm{KCl}$ for enzyme dissociation in both the presence and absence of $0.12 \% \beta$-mercaptoethanol was $0.5 \mathrm{M}$. No optimal concentration of $\beta$-mercaptoethanol was found in the presence of a constant amount of $\mathrm{KCl}$. The amount of activity eluted in a 30 -min period increased with increasing thiol concentrations up to $0.5 \%$ (Table $3)$. Other experiments indicated that the rate of elution may be larger at even higher concentrations of thiol.

The rate at which acid phosphatase may be dissociated from cells was a function of $p \mathrm{H}$. The higher the $p \mathrm{H}$, the faster the enzyme was eluted (Fig. 1). The loss of activity at $p \mathrm{H} 8$ was due to the instability of enzyme at $p \mathrm{H}$ values above 7 (Weimberg and Orton, 1963). Therefore, it was not possible to study the rate of elution in the alkaline range.

Other sulfhydryl compounds substituted for $\beta$-mercaptoethanol in stimulating the dissociation of acid phosphatase from resting cells in the presence of $\mathrm{KCl}$ (Table 4). This seems to be a property of the sulfhydryl group, since other reducing agents were not effective. The only exception was sodium bisulfite. Both 1,2-dimercapto-1-propanol and ascorbate in the presence 
of $\mathrm{KCl}$ inactivated the enzyme. Iodoacetate, which reacts with sulfhydryl groups, and 5,5'dithiobis(2-nitrobenzoic acid), which substitutes for disulfide-linked residues, were without effect on the system.

Potassium chloride may be replaced by any number of salts that ionize in water (Table 5) for the process of removing acid phosphatase from resting cells. These other salts, when present in high enough concentration along with thiol and snail-gut extract, were also effective in stabilizing protoplasts. On the other hand, neutral compounds were unsatisfactory for eluting acid phosphatase from cells. At no concentration of a nonionizable substance, like urea, sucrose, or sorbitol, was any acid phosphatase dissociated from the cells with or without thiol. The enzyme system, however, was inactivated in $8 \mathrm{~m}$ urea.

These neutral compounds were also unable to act as stabilizing agents for protoplasts. In the presence of $4 \mathrm{M}$ sorbitol, snail extract, and $\beta$ mercaptoethanol, cells of $S$. mellis lysed after 3 to $6 \mathrm{hr}$ of incubation. No protoplasts were detected before lysis occurred. By use of conditions under which the acid phosphatase activity was protected (pretreating the cells with thiol and then incubating the cells in a reaction mixture containing $4 \mathrm{~m}$ sorbitol, snail extract, and arsenite), acid phosphatase was not detected in the supernatant fraction until after $3 \mathrm{hr}$ or more of incubation at $30 \mathrm{C}$, which is approximately the same time that the cells were lysing in the reaction mixture. Similar results were obtained when sorbitol was replaced with a nearly saturated solution of sucrose or with water. We concluded, therefore, that nonionizable compounds do not serve as stabilizing agents for protoplasts of $S$. mellis, in addition to being unable to dissociate enzyme from the cell surface. The function of salts, both for maintaining protoplast structure and for eluting acid phosphatase, appears to be more involved than merely to provide an isotonic solution.

Since a pretreatment of cells with a thiol proved effective in the process of protoplast formation (Weimberg and Orton, 1964), it was decided to determine what effect the stepwise treatment of cells with $\beta$-mercaptoethanol and $\mathrm{KCl}$ would have on acid phosphatase dissociation (Table 6). Incubation of cells in $\beta$-mercaptoethanol, followed by an incubation period in $2 \mathrm{M}$ salt, resulted in the elution of only a small amount of enzymatic activity. On the other hand, if cells were first treated with $2 \mathrm{~m}$ salt and then suspended in a medium containing thiol, a large amount of enzymatic activity was rapidly eluted. In similar experiments in which rates of elution were determined, it was found that the enzyme

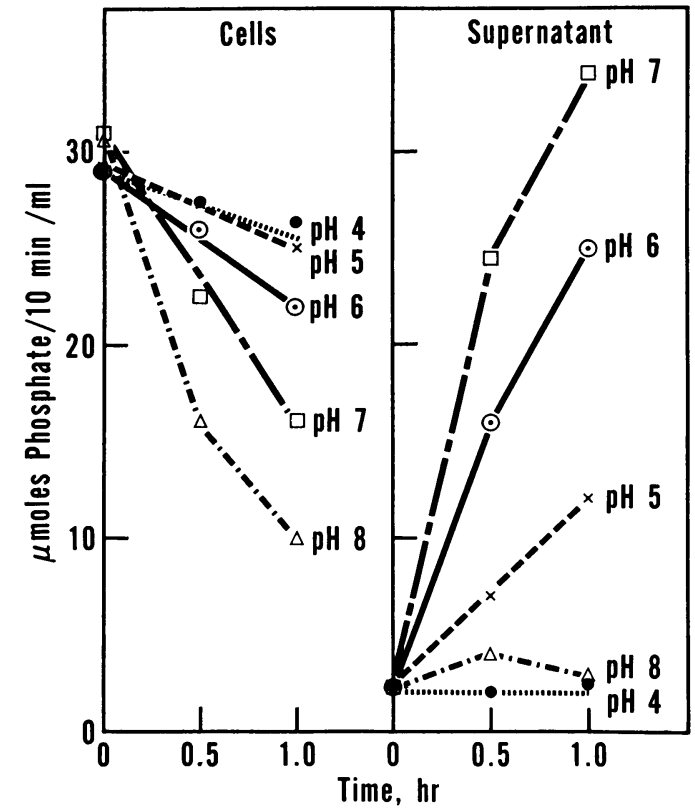

Fig. 1. Effect of $p H$ on elution of acid phosphatase. $A$ series of reaction mixtures at different $p H$ values, each containing $2.0 \mathrm{ml}$ of resting cells $(0.3$ $\mathrm{g} / \mathrm{ml}$ of water), $0.2 \mathrm{ml}$ of $1.0 \mathrm{M}$ buffer, $1.0 \mathrm{ml}$ of $2 \mathrm{M}$ $\mathrm{KCl}$, and $0.8 \mathrm{ml}$ of water, was incubated at $30 \mathrm{C}$. At the intervals shown on the abscissa, $1.0 \mathrm{ml}$ was removed and centrifuged; the cells were suspended in $1.0 \mathrm{ml}$ of water, and cells and supernatant fractions were assayed for acid phosphatase activity. Acetate buffer was used for $p H$ 4, 5, and 6; Tris buffer was used for $\mathrm{pH} 7$ and 8 .

is eluted at a more rapid rate by being treated with reagents in a stepwise manner rather than simultaneously. This result is rather surprising in view of the ability of lower salt concentrations to extract the enzyme without the aid of any thiol reagent.

The chemical composition of isolated yeast cell walls has been studied, and various components have been identified (for review, see Phaff, 1963). The walls seem to be composed mainly of carbohydrate polymers, with lesser amounts of lipid and protein. The eluates obtained by incubating resting cells of $S$. mellis in $\beta$-mercaptoethanol and in $\mathrm{KCl}$ were analyzed for their total carbohydrate and protein content to see whether any of these cell-wall constituents were removed from the cells along with enzymatic activity by these treatments.

Significant amounts of both carbohydrate and protein were extracted with $\beta$-mercaptoethanol (Table 6). Salt extractions removed mainly carbohydrate, although some protein was also dissociated. A lesser quantity of protein was extracted 
at higher salt concentrations. It is noteworthy that the protein extracted with thiol or $2 \mathrm{~m} \mathrm{KCl}$ had no acid phosphatase activity. Although the extractions listed in Table 6 are not exhaustive, they do show that, after $\beta$-mercaptoethanol treatment, some carbohydrate and protein are left on the cell surface which are extractable with $2 \mathrm{M} \mathrm{KCl}$.

$\mathrm{T}_{\mathrm{ABLE}}$ 4. Elution of acid phosphatase from resting cells in $2 \mathrm{M} \mathrm{KCl}$ by thiols and related agents

\begin{tabular}{|c|c|c|c|c|c|}
\hline \multirow{3}{*}{ Reagent } & \multirow{3}{*}{ Concn } & \multicolumn{4}{|c|}{ Activity* } \\
\hline & & \multicolumn{2}{|c|}{ In cells } & \multicolumn{2}{|c|}{ In supernatant fluid } \\
\hline & & Initial & Final & Initial & Final \\
\hline & $M$ & & & & \\
\hline Water. & & 39.0 & 43.5 & 1.2 & 1.4 \\
\hline$\beta$-Mercaptoethanol. & 0.02 & 54.0 & 22.0 & 1.0 & 35.5 \\
\hline Cysteine. . & 0.02 & 53.3 & 16.0 & 1.1 & 47.0 \\
\hline Sodium sulfide.. & 0.02 & 48.4 & 15.0 & 1.1 & 47.0 \\
\hline Sodium bisulfite. & 0.02 & 50.1 & 14.6 & 0.7 & 53.8 \\
\hline 2,3-Dimercapto-1-propanol & 0.02 & 7.4 & 0.7 & 0.7 & 0.7 \\
\hline Potassium cyanide.. & 0.02 & 42.5 & 48.4 & 1.6 & 1.3 \\
\hline Sodium arsenite. & 0.02 & 47.7 & 44.0 & 1.5 & 1.7 \\
\hline Sodium ascorbate.. & 0.02 & 20.9 & 10.8 & 0.5 & 0.5 \\
\hline Ferrous sulfate. & 0.02 & 32.0 & 30.0 & 0 & 0 \\
\hline Sodium iodoacetate. & 0.02 & 46.4 & 43.2 & 1.1 & 3.5 \\
\hline $5,5^{\prime}$-Dithiobis (2-nitrobenzoic acid). & 0.02 & 42.1 & 42.5 & 1.4 & 1.7 \\
\hline
\end{tabular}

* All values are expressed as micromoles of phosphate per 10 min per milliliter. Reaction mixtures contained the following: $1.0 \mathrm{ml}$ of resting cells of $S$. mellis $(0.3 \mathrm{~g} / \mathrm{ml}) ; 0.15 \mathrm{ml}$ of $1.0 \mathrm{M}$ acetate buffer $(p \mathrm{H}$ $6.5) ; 1.5 \mathrm{ml}$ of $4 \mathrm{M} \mathrm{KCl} ; 0.3 \mathrm{ml}$ of $0.2 \mathrm{M}$ reagent; $0.05 \mathrm{ml}$ of water. The reaction mixtures were incubated at $30 \mathrm{C}$. Initially and after $60 \mathrm{~min}$ of incubation, $1.0-\mathrm{ml}$ samples were removed from each reaction mixture and centrifuged, and the cells were suspended in $1.0 \mathrm{ml}$ of water. The supernatant fractions and suspended cells were assayed for acid phosphatase activity. All reagents were adjusted to a $p H$ near 6.5 before use.

TABLE 5. Elution of acid phosphatase by salts and other reagents

\begin{tabular}{|c|c|c|c|c|c|}
\hline \multirow{3}{*}{ Reagent } & \multirow{3}{*}{ Concn } & \multicolumn{4}{|c|}{ Activity* } \\
\hline & & \multicolumn{2}{|c|}{ In cells } & \multicolumn{2}{|c|}{ In supernatant fluid } \\
\hline & & Initial & Final & Initial & Final \\
\hline & $M$ & & & & \\
\hline Water. & & 30.5 & 32.5 & 1.5 & 1.5 \\
\hline $\mathrm{KCl} \ldots$ & 0.24 & 32.0 & 15.1 & 2.0 & 35.0 \\
\hline $\mathrm{NaCl}$ & 0.24 & 30.5 & 19.0 & 1.0 & 28.0 \\
\hline Potassium acetate.. & 0.24 & 30.0 & 19.5 & 1.5 & 25.0 \\
\hline Sodium acetate.... & 0.24 & 28.5 & 22.0 & 1.0 & 20.5 \\
\hline$\left(\mathrm{NH}_{4}\right)_{2} \mathrm{SO}_{4} \ldots \ldots$ & 0.24 & 32.5 & 13.0 & 1.5 & 35.6 \\
\hline $\mathrm{NH}_{4} \mathrm{Cl} \ldots \ldots \ldots$ & 0.24 & 31.5 & 19.0 & 1.5 & 27.0 \\
\hline Tris.... & 0.16 & 28.0 & 20.0 & 1.5 & 26.0 \\
\hline Ethylenediaminetetraacetic acid. & 0.24 & 30.0 & 1.0 & 1.2 & 38.0 \\
\hline Urea. . . $\ldots \ldots \ldots \ldots \ldots \ldots$ & 0.48 & 28.5 & 29.0 & 1.0 & 1.5 \\
\hline Sorbitol. & 0.40 & 27.5 & 29.0 & 1.0 & 1.0 \\
\hline Sucrose. & 0.48 & 29.0 & 27.5 & 1.0 & 1.0 \\
\hline
\end{tabular}

* All values are expressed as micromoles of phosphate per 10 min per milliliter. Each reaction mixture contained $2.0 \mathrm{ml}$ of resting cells of $S$. mellis $(0.2 \mathrm{~g} / \mathrm{ml}), 0.1 \mathrm{ml}$ of $1.0 \mathrm{M}$ acetate buffer $(p \mathrm{H} 6.5), 0.2 \mathrm{ml}$ of reagent, and $0.2 \mathrm{ml}$ of water. Samples $(1.0 \mathrm{ml})$ were removed initially and after $60 \mathrm{~min}$ of incubation at $30 \mathrm{C}$ and centrifuged, and the cells were suspended in $1.0 \mathrm{ml}$ of water. Cells and supernatant fractions were assayed for phosphatase activity. Concentration of all the salts was $3 \mathrm{~m}$, except tris(hydroxymethyl)aminomethane (Tris) which was $2 \mathrm{~m}$. Urea concentration was $6 \mathrm{~m}$; sorbitol, $5 \mathrm{~m}$; and sucrose, $3 \mathrm{~m}$ $(0.4 \mathrm{ml}$ of this reagent was added to the reaction mixture). All reagents were adjusted to approximately $p \mathrm{H} 6.5$ before use. 
TABLE 6. Effect of pretreatment of Saccharomyces mellis with $\mathrm{KCl}$ or $\beta$-mercaptoethanol on elution of acid phosphatase*

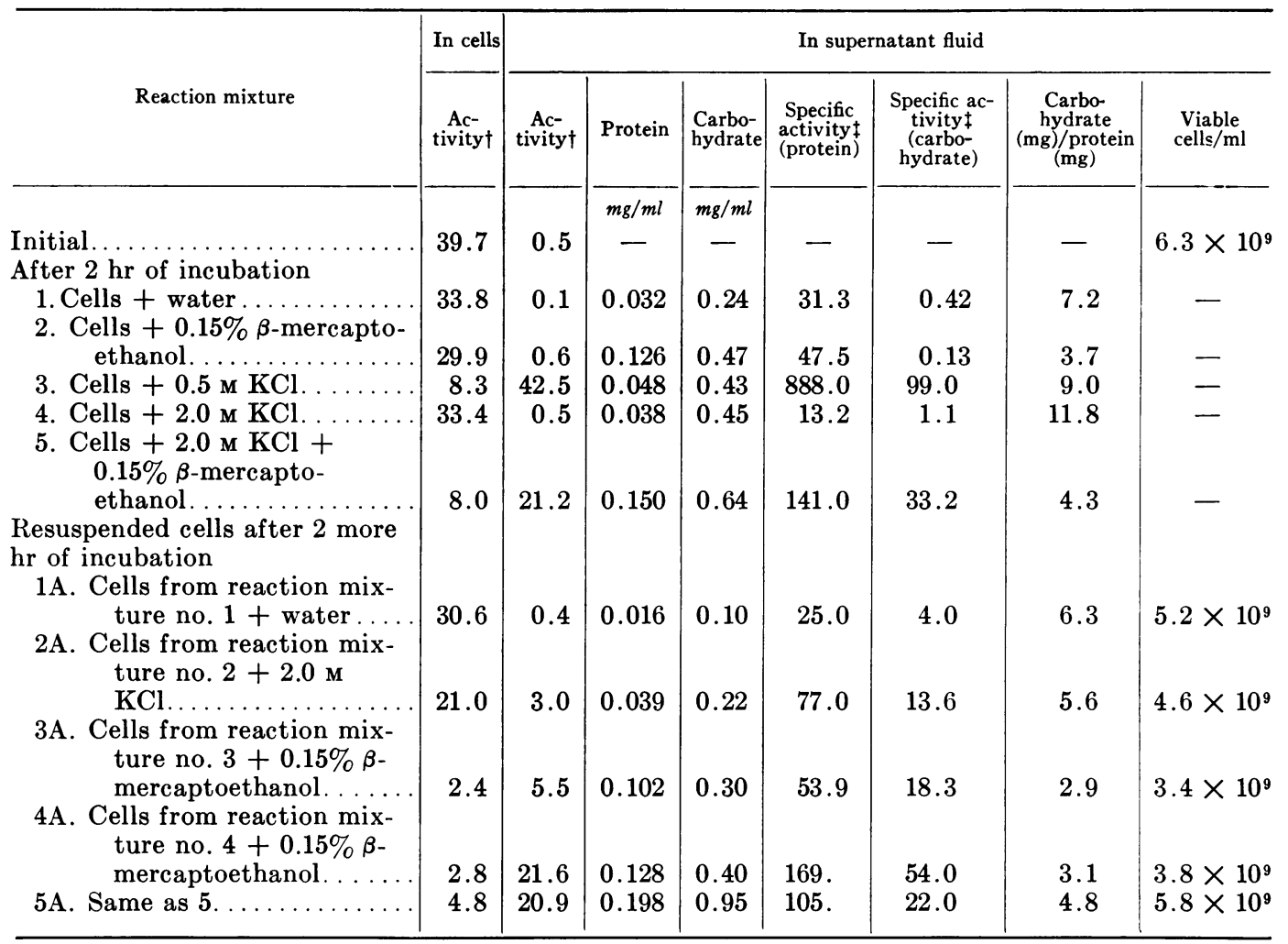

* A resting-cell suspension of $S$. mellis was prepared in $0.167 \mathrm{~m}$ acetate buffer $(p \mathrm{H} 6.5)$ at a concentration of $0.33 \mathrm{~g} / \mathrm{ml}$. A volume of $1.5 \mathrm{ml}$ of cells was mixed with either $4 \mathrm{M} \mathrm{KCl}$ or $3 \% \beta$-mercaptoethanol, or both, to give the concentration listed in a volume of $5 \mathrm{ml}$. The reaction mixtures were incubated for 2 $\mathrm{hr}$ and then centrifuged. The cells were washed once in ice-cold water before being suspended in $1.5 \mathrm{ml}$ of $0.167 \mathrm{~m}$ acetate buffer $(p \mathrm{H} \mathrm{6.5)}$ and added to the reagents, as listed in the second series of reaction mixtures, in a final volume of $5 \mathrm{ml}$. The second series was assayed immediately for acid phosphatase to determine activity in the cells. They were then incubated for $2 \mathrm{hr}$ at $30 \mathrm{C}$. The reaction was stopped by centrifuging the cells, which were then suspended in $5 \mathrm{ml}$ of water. Cells and supernatant fractions were assayed for acid phosphatase activity.

$\dagger$ Expressed as micromoles of $\mathrm{PO}_{4}^{-3}$ per $10 \mathrm{~min}$ per milliliter.

$\ddagger$ Expressed as micromoles of $\mathrm{PO}_{4}^{-3}$ per 10 min per milligram of protein or carbohydrate.

The nondialyzable carbohydrate polymer in the extracts was identified as a mannan. The extracts were adjusted to contain $2 \mathrm{~N} \mathrm{HCl}$, and were then placed in a boiling-water bath for $2 \mathrm{hr}$ to hydrolyze the polymer. Chromatograms of each hydrolyzed extract, developed in butanolpyridine-water $(6: 4: 3)$ and in ethyl acetateacetic acid-pyridine-water $(5: 1: 5: 3)$, showed the presence of a reducing sugar whose $R_{F}$ value corresponded to that of mannose. No other reducing sugars were detected.

Acid phosphatase (as well as other cellular constituents that are extracted by $\mathrm{KCl}$ and $\beta$ mercaptoethanol) is not essential for viability. Cells treated with $0.5 \mathrm{M} \mathrm{KCl}$ or with $2 \mathrm{M} \mathrm{KCl}$ plus $0.3 \% \beta$-mercaptoethanol were able to grow as rapidly as untreated cells, and there was only a small decrease in the total number of viable cells (Table 6). The cells even retained the ability to synthesize new enzyme, since treated cells with most of the phosphatase activity removed quickly regain it when grown in a medium initially very low in inorganic phosphate.

Elution of acid phosphatase from acetone-dried cells. Previous studies reported that acid phosphatase could be dissociated from leached acetone-dried cells of $S$. mellis only with papain or by digesting the cell wall with snail-gut extract (Weimberg and Orton, 1964). In view of the results obtained with resting cells, the phenomenon 
TABLE 7. Effect of various concentrations of $\mathrm{KCl}$ on elution of acid phosphatase from acetonedried cells in presence and absence of $\beta$-mercaptoethanol

\begin{tabular}{|c|c|c|c|c|c|}
\hline \multirow{3}{*}{$\underset{\text { salt }}{\text { Concn of }}$} & \multirow{3}{*}{$\begin{array}{c}\text { Presence of } \beta \text { - } \\
\text { mercaptoethanol }\end{array}$} & \multicolumn{4}{|c|}{ Activity* } \\
\hline & & \multicolumn{2}{|c|}{ In cells } & \multicolumn{2}{|c|}{$\begin{array}{l}\text { In supernatant } \\
\text { fluid }\end{array}$} \\
\hline & & Initial & Final & Initial & Final \\
\hline$M$ & & & & & \\
\hline 0 & \pm & $\begin{array}{l}33.0 \\
34.0\end{array}$ & $\begin{array}{l}40.6 \\
34.8\end{array}$ & $\begin{array}{l}1.0 \\
0.5\end{array}$ & $\begin{array}{l}2.3 \\
2.0\end{array}$ \\
\hline 0.1 & $\begin{array}{l}+ \\
-\end{array}$ & $\begin{array}{l}35.0 \\
32.6\end{array}$ & $\begin{array}{l}30.2 \\
31.6\end{array}$ & $\begin{array}{l}0.6 \\
0.4\end{array}$ & $\begin{array}{l}2.9 \\
2.0\end{array}$ \\
\hline 0.5 & \pm & $\begin{array}{l}33.0 \\
28.5\end{array}$ & $\begin{array}{l}21.5 \\
34.8\end{array}$ & $\begin{array}{l}0.6 \\
1.0\end{array}$ & $\begin{array}{r}20.6 \\
2.2\end{array}$ \\
\hline 1.0 & + & $\begin{array}{l}32.0 \\
30.9\end{array}$ & $\begin{array}{l}20.8 \\
32.0\end{array}$ & $\begin{array}{l}0.7 \\
0.6\end{array}$ & $\begin{array}{r}14.6 \\
2.2\end{array}$ \\
\hline 2.0 & + & $\begin{array}{l}32.6 \\
31.2\end{array}$ & $\begin{array}{l}23.6 \\
33.3\end{array}$ & $\begin{array}{l}0.6 \\
0.5\end{array}$ & $\begin{array}{r}10.8 \\
1.9\end{array}$ \\
\hline
\end{tabular}

* All values are expressed as micromoles of phosphate per 10 min per milliliter. Conditions are the same as in Table 2, except that acetonedried cells suspended in water at a concentration of $0.05 \mathrm{~g} / \mathrm{ml}$ were used, and the activity in suspended cells and reaction-mixture supernatant fractions was determined after 120 min of incubation.

of removing acid phosphatase from acetonedried cells was also reinvestigated. In general, the conditions under which acid phosphatase may be eluted from acetone-dried cells are the same as those reported for resting cells. A mixture of $\beta$-mercaptoethanol and $\mathrm{KCl}$ eluted enzymatic activity, and the optimal concentration of $\mathrm{KCl}$ for elution was $0.5 \mathrm{M}$ (Table 7 ). $\beta$-Mercaptoethanol alone eluted no phosphatase activity, as previously reported (Weimberg and Orton, 1064). However, unlike resting cells, the presence of $\beta$-mercaptoethanol was required for acid phosphatase extraction at all concentrations of salt.

Other salts replaced $\mathrm{KCl}$ in the system, but neutral compounds like urea, sucrose, sorbitol, rhamnose, or mannitol did not. Other thiols and sodium bisulfite replaced $\beta$-mercaptoethanol but not the other reducing agents tested. If the cells were treated with the reagents in a stepwise manner, enzyme was dissociated when the cells were incubated in $\beta$-mercaptoethanol followed by $2 \mathrm{M} \mathrm{KCl}$, but not when the cells were incubated in these reagents in the reverse order (Table 8). This result is rather anomolous since it is the opposite of the effects of these two reagents on resting cells.

Drying cells of $S$. mellis in acetone seemed to alter the mechanism of attachment of some of the acid phosphatase to the cell surface. In resting cells, the eluting reagents extracted almost all enzymatic activity (Table 1). Lsually, after incubating the cells in these reagents for several hours, less than $5 \%$ remains attached to the cells. With acetone-dried cells, however, the enzyme was eluted more slowly, and it was never possible to elute all activity (Fig. 2). Approximately 25 to $40 \%$ of the initial activity remained associated with the particulate fraction. In addition, there was a large increase in enzymatic activity in cells incubated in reaction mix-

TABLE 8. Effect of pretreatment of acetone-dried cells with $K C l$ or $\beta$-mercaptoethanol on elution of acid phosphatase

\begin{tabular}{|c|c|c|c|c|}
\hline \multirow{3}{*}{ Reaction mixture } & \multicolumn{4}{|c|}{ Activity* } \\
\hline & \multicolumn{2}{|c|}{ In cells } & \multicolumn{2}{|c|}{$\begin{array}{l}\text { In supernatan } \\
\text { fluid }\end{array}$} \\
\hline & Initial & Final & Initial & Final \\
\hline $\begin{array}{l}\text { Cells pretreated with } \\
0.3 \% \beta \text {-mercapto- } \\
\text { ethanol }\end{array}$ & & & & \\
\hline + water... & 50.0 & 52.2 & 0.1 & 0.3 \\
\hline $\begin{array}{l}+2 \mathrm{M} \mathrm{KCl} \ldots \\
+2 \mathrm{M} \mathrm{KCl}+0.15 \%\end{array}$ & 51.1 & 27.1 & 1.8 & 17.8 \\
\hline $\begin{array}{l}\beta \text {-mercaptoethanol } \\
\text { Cells pretreated with } \\
0.4 \mathrm{M} \mathrm{KCl}\end{array}$ & 48.0 & 23.7 & 1.8 & 17.8 \\
\hline $\begin{array}{l}+ \text { water............. } \\
+0.3 \% \beta \text {-mercapto- }\end{array}$ & 26.0 & 27.5 & 0.1 & 0 \\
\hline $\begin{array}{r}\text { ethanol........ } \\
+2 \mathrm{M} \mathrm{KCl}+0.15 \%\end{array}$ & 25.4 & 33.0 & 0.1 & 0 \\
\hline$\beta$-mercaptoethanol & 24.7 & 23.1 & 0.1 & 9.0 \\
\hline
\end{tabular}

* All values are expressed as micromoles of phosphate per 10 min per milliliter. To $4.8 \mathrm{ml}$ of a suspension of acetone-dried cells of $S$. mellis $(0.1 \mathrm{~g} / \mathrm{ml})$ were added $0.6 \mathrm{ml}$ of acetate buffer $(p \mathrm{H} 6.5)$ and either $0.6 \mathrm{ml}$ of $3 \% \quad \beta$-mercaptoethanol or $0.6 \mathrm{ml}$ of $4 \mathrm{M} \mathrm{KCl}$. These reaction mixtures were incubated for $4 \mathrm{hr}$ at $30 \mathrm{C}$ and then centrifuged; the cells were washed in water and suspended in $4.8 \mathrm{ml}$ of water. Elution of enzyme was measured in reaction mixtures containing $1.5 \mathrm{ml}$ of treated cells; $0.1 \mathrm{ml}$ of $1.0 \mathrm{M}$ acetate buffer $(p \mathrm{H} 6.5)$; either $2.0 \mathrm{ml}$ of $4 \mathrm{M} \mathrm{KCl}$ or $0.2 \mathrm{ml}$ of $3 \%$ $\beta$-mercaptoethanol, or both; and water so that the final volume was $4.0 \mathrm{ml}$. Samples of $1.0 \mathrm{ml}$ were removed initially and after $2 \mathrm{hr}$ of incubation at $30 \mathrm{C}$. Cells were collected by centrifugation and suspended in $1.0 \mathrm{ml}$ of water. Acid phosphatase activity was measured in the suspended cells and in the supernatant fractions. 
TABLE 9. Recovery of acid phosphatase as an extracellular enzyme by growing Saccharomyces mellis in media containing $\mathrm{KCl}^{a}$

\begin{tabular}{|c|c|c|c|c|c|c|}
\hline \multirow[b]{2}{*}{$\begin{array}{l}\text { Concn } \\
\text { of } \mathrm{KCl}\end{array}$} & \multirow[b]{2}{*}{$\begin{array}{l}\text { Incu- } \\
\text { bation } \\
\text { period }\end{array}$} & \multirow{2}{*}{$\begin{array}{c}\text { Wet wt } \\
\text { of cells/ } \\
100 \mathrm{ml} \\
\text { of } \\
\text { media }\end{array}$} & \multicolumn{2}{|c|}{ Activity } & \multirow[b]{2}{*}{$\begin{array}{l}\text { Specific } \\
\text { activity } \\
\text { of cells }\end{array}$} & \multirow[b]{2}{*}{$\begin{array}{l}\text { Specific } \\
\text { activity } \\
\text { of media }\end{array}$} \\
\hline & & & $\begin{array}{l}\text { In cells } \\
\text { from } 100 \\
\text { ml of } \\
\text { media }^{b}\end{array}$ & $\begin{array}{l}\text { In } 100 \\
\text { ml of } \\
\text { media }^{c}\end{array}$ & & \\
\hline$M$ & days & $g$ & & & & \\
\hline 0 & $\begin{array}{l}1 \\
2 \\
3 \\
4 \\
5\end{array}$ & $\begin{array}{l}1.30 \\
1.65 \\
1.80 \\
1.95 \\
1.90\end{array}$ & $\begin{array}{l}305 \\
513 \\
569 \\
654 \\
636\end{array}$ & $\begin{array}{c}0 \\
28.5 \\
28.5 \\
57.0 \\
48.0\end{array}$ & $\begin{array}{l}235 \\
311 \\
316 \\
335 \\
335\end{array}$ & $\begin{array}{c}0 \\
17.3 \\
15.8 \\
29.2 \\
25.2\end{array}$ \\
\hline 0.05 & $\begin{array}{l}1 \\
2 \\
3 \\
4 \\
5\end{array}$ & $\begin{array}{l}1.50 \\
1.85 \\
2.00 \\
2.20 \\
2.50\end{array}$ & $\begin{array}{l}390 \\
537 \\
590 \\
550 \\
450\end{array}$ & $\begin{array}{c}0 \\
28.5 \\
171 \\
285 \\
515\end{array}$ & $\begin{array}{l}260 \\
290 \\
294 \\
250 \\
180\end{array}$ & $\begin{array}{c}0 \\
15.4 \\
85.5 \\
129 \\
206\end{array}$ \\
\hline 0.1 & $\begin{array}{l}1 \\
2 \\
3 \\
4 \\
5\end{array}$ & $\begin{array}{l}1.45 \\
1.80 \\
2.10 \\
2.20 \\
2.15\end{array}$ & $\begin{array}{l}362 \\
487 \\
410 \\
363 \\
237\end{array}$ & $\begin{array}{r}143 \\
457 \\
1,000 \\
1,285 \\
1,300\end{array}$ & $\begin{array}{l}250 \\
270 \\
195 \\
165 \\
110\end{array}$ & $\begin{array}{l}98.5 \\
254 \\
475 \\
585 \\
605\end{array}$ \\
\hline 0.2 & $\begin{array}{l}1 \\
2 \\
3 \\
4 \\
5\end{array}$ & $\begin{array}{l}1.45 \\
1.65 \\
1.95 \\
2.35 \\
2.40\end{array}$ & $\begin{array}{l}167 \\
165 \\
161 \\
141 \\
132\end{array}$ & $\begin{array}{r}665 \\
1,370 \\
1,830 \\
1,950 \\
2,100\end{array}$ & $\begin{array}{c}115 \\
100 \\
82.5 \\
60.0 \\
55.0\end{array}$ & $\begin{array}{l}460 \\
830 \\
940 \\
830 \\
875\end{array}$ \\
\hline 0.25 & $\begin{array}{l}1 \\
2 \\
3 \\
4 \\
5\end{array}$ & $\begin{array}{l}1.50 \\
1.80 \\
2.05 \\
2.35 \\
2.45\end{array}$ & $\begin{array}{l}120 \\
126 \\
164 \\
190 \\
220\end{array}$ & $\begin{array}{r}770 \\
1,115 \\
1,940 \\
3,150 \\
4,600\end{array}$ & $\begin{array}{l}80.0 \\
70.0 \\
80.0 \\
81.0 \\
90.0\end{array}$ & $\begin{array}{r}515 \\
640 \\
945 \\
1,340 \\
1,880\end{array}$ \\
\hline 0.5 & $\begin{array}{l}1 \\
2 \\
3 \\
4 \\
5\end{array}$ & $\begin{array}{l}1.50 \\
1.70 \\
1.85 \\
2.05 \\
2.10\end{array}$ & $\begin{array}{l}75.0 \\
110 \\
102 \\
132 \\
130\end{array}$ & $\begin{array}{r}570 \\
1,000 \\
1,200 \\
885 \\
700\end{array}$ & $\begin{array}{l}50.0 \\
65.0 \\
55.2 \\
64.5 \\
62.0\end{array}$ & $\begin{array}{l}380 \\
588 \\
650 \\
432 \\
333\end{array}$ \\
\hline 1.0 & $\begin{array}{l}1 \\
2 \\
3 \\
4 \\
5\end{array}$ & $\begin{array}{l}1.30 \\
1.75 \\
1.95 \\
2.20 \\
2.10\end{array}$ & $\begin{array}{l}39.0 \\
61.5 \\
58.5 \\
50.5 \\
37.5\end{array}$ & $\begin{array}{l}600 \\
570 \\
715 \\
685 \\
466\end{array}$ & $\begin{array}{l}30.0 \\
35.2 \\
30.0 \\
23.0 \\
17.9\end{array}$ & $\begin{array}{l}461 \\
325 \\
367 \\
312 \\
222\end{array}$ \\
\hline 2.0 & $\begin{array}{l}1 \\
2 \\
3 \\
4 \\
5\end{array}$ & $\begin{array}{l}1.00 \\
1.45 \\
1.85 \\
2.20 \\
2.05\end{array}$ & $\begin{array}{r}0 \\
7.5 \\
9.5 \\
11.0 \\
7.5\end{array}$ & $\begin{array}{r}233 \\
287 \\
200 \\
115 \\
90\end{array}$ & $\begin{array}{l}0 \\
5.2 \\
5.1 \\
5.0 \\
3.7\end{array}$ & $\begin{array}{c}233 \\
198 \\
108 \\
52.3 \\
44.0\end{array}$ \\
\hline
\end{tabular}

${ }^{a}$ Flasks with $200 \mathrm{ml}$ of media containing $10 \%$ glucose, $0.1 \%$ urea, $0.5 \%$ yeast extract (treated with magnesia to remove inorganic phosphate), and various amounts of $\mathrm{KCl}$ were inoculated with $10 \mathrm{ml}$ of a fully grown culture of $S$. mellis and incubated aerobically at $28 \mathrm{C}$. At 24 -hr intervals, 20 -ml samples were removed; the cells were harvested, washed in water, and suspended in water at a concentration of $0.2 \mathrm{~g} / \mathrm{ml}$. The cells and the culture supernatant fluids were assayed for acid phosphatase activity.

${ }^{b}$ Expressed as micromoles of $\mathrm{PO}_{4}^{-3}$ per $10 \mathrm{~min}$ per total weight of cells.

${ }^{c}$ Expressed as micromoles of $\mathrm{PO}_{4}^{-3}$ per $10 \mathrm{~min}$ per $100 \mathrm{ml}$.

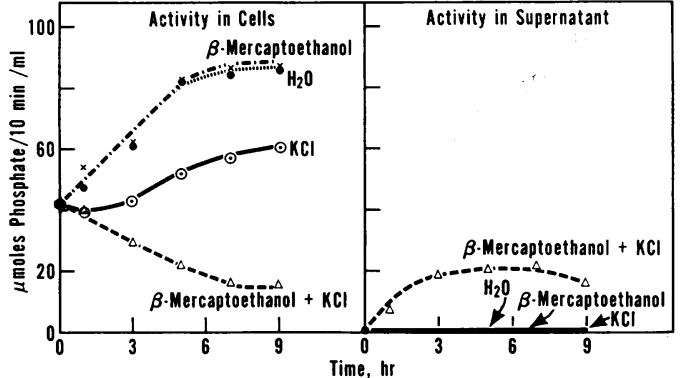

FIG. 2. Acid phosphatase activity in acetonedried cells of Saccharomyces mellis after treatment with $\beta$-mercaptoethanol and $\mathrm{KCl}$. The acetone-dried cells were suspended in water at a concentration of $0.1 \mathrm{~g} / \mathrm{ml}$. To $2.0 \mathrm{ml}$ of cells were added $0.2 \mathrm{ml}$ of $1.0 \mathrm{M}$ acetate buffer ( $p H$ 6.5), either $0.3 \mathrm{ml}$ of $3 \% \beta$ mercaptoethanol or $3.0 \mathrm{ml}$ of $4 \mathrm{M} \mathrm{KCl}$, or both, and water so that the final volume was $6.0 \mathrm{ml}$. At the intervals shown on the abscissa, 1.0-ml samples were removed, the reaction mixture was centrifuged, and the cells were suspended in $1.0 \mathrm{ml}$ of water. The cells and supernatant fractions were assayed for enzymatic activity.

tures in which enzyme dissociation cannot occur. Although this increase in activity of acid phosphatase remaining attached to the cell was observed in resting cells also, it was not as marked as with acetone-dried cells. The reason for this increase in activity is not apparent from these experiments.

Elution of acid phosphatase from growing cells. Since acid phosphatase was eluted from resting cells by salts without affecting viability, it seemed possible that inclusion of $\mathrm{KCl}$ in growth media might remove the enzyme from the cells as it is formed. S. mellis was grown in a series of flasks containing media with various amounts of $\mathrm{KCl}$. Samples were removed at intervals, and the enzyme activity on the cells and in the culture medium was determined (Table 9). Enzymatic activity was found in the medium over a large range of salt concentrations. The rate of growth did not seem to be seriously affected by salt until the concentration was aroung $2 \mathrm{~m}$. The optimal concentration for maximal yield of activity was $0.25 \mathrm{M} \mathrm{KCl}$. The amount of activity detectable under these conditions was approximately eight times more than the maximal amount present on cells grown in a medium to which no $\mathrm{KCl}$ was added. In other experiments, even larger yeilds of extracellular enzyme were obtained in media containing $0.25 \mathrm{~m}$ salt.

Although growth in $0.25 \mathrm{M} \mathrm{KCl}$ resulted in phosphatase activity appearing as an extracellu-

${ }^{d}$ Expressed as micromoles of $\mathrm{PO}_{4}^{-3}$ per $10 \mathrm{~min}$ per gram of cells. 
lar enzyme, it was never possible to obtain enzyme-free cells. Thus, if these cells are transferred to an inorganic phosphate-free medium, they are still capable of growing on any organic phosphomonoesters present.

Purification studies on the extracellular acid phosphatase. Large yields of acid phosphatase in the supernatant fluid of a growing culture of $S$. mellis were obtainable simply by including 0.25 $\mathbf{M ~ K C l ~ i n ~ t h e ~ m e d i u m . ~ S u c h ~ c u l t u r e ~ f l u i d ~ w i t h ~ a ~}$ large amount of activity seemed to be good starting material for trying to purify the enzyme. In initial studies, we found it impossible to remove the enzyme from culture medium by ammonium sulfate precipitation, since no precipitate formed in the culture fluid even in a saturated solution of this salt. The acid phosphatase could be precipitated by adding 1.5 volumes of either cold acetone or ethyl alcohol to the medium. The precipitate was gummy and adhered to the side of the flask. The reaction mixture was allowed to stand several hours in the cold to allow the precipitate to settle out. The supernatant liquid was removed by decanting and was discarded. The gummy precipitate was water-soluble and, after being dissolved, was precipitated a second time with an equivalent volume of acetone. Although the gum may be converted to an amorphous powder by triturating the precipitate several times with acetone, it usually was dissolved in water for further studies. Like the constituents eluted from resting cells by $\beta$-mercaptoethanol and $\mathrm{KCl}$, the acetone-insoluble material from crude culture media contained protein and carbohydrate (Table 10). As shown chromatographically, the carbohydrate was a mannan. No glucose or other sugar was found on the chromatograms. The mannan present in the acetone-insoluble material is probably closely associated with protein, since it is not precipitated by alkaline copper reagents even after being boiled for $60 \mathrm{~min}$ in $1 \mathrm{~N} \mathrm{NaOH}$ (Cifonelli and Smith, 1955; Kessler and Nickerson, 1959).

The molecular weight of these constituents is probably very large, as shown by Sephadex gel filtration. A 1-ml amount of the enzyme solution, precipitated with acetone twice and dissolved in water, was placed on a column (2 by $12 \mathrm{~cm}$ ) of Sephadex G-200 equilibrated in $0.01 \mathrm{~m}$ acetate

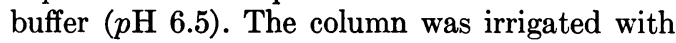
the same buffer at the rate of $6 \mathrm{ml} / \mathrm{hr}$. Eluates $(2 \mathrm{ml})$ were collected and assayed for enzymatic activity, carbohydrate, and protein. All enzymatic activity and almost all the protein and carbohydrate were eluted before more than 14 $\mathrm{ml}$ of the buffer passed through the column. Since the constituents and activity were eluted in the excluded volume of the gel, the molecular weights of these compounds or any complexes they may form with one another are probably greater than 200,000 as estimated by this method.

Some purification of the enzyme was possible with calcium phosphate gel adsorption and elution. A 10-ml amount of calcium phosphate gel

TABLE 10. Purification procedure of acid phosphatase produced extracellularly by growing cells

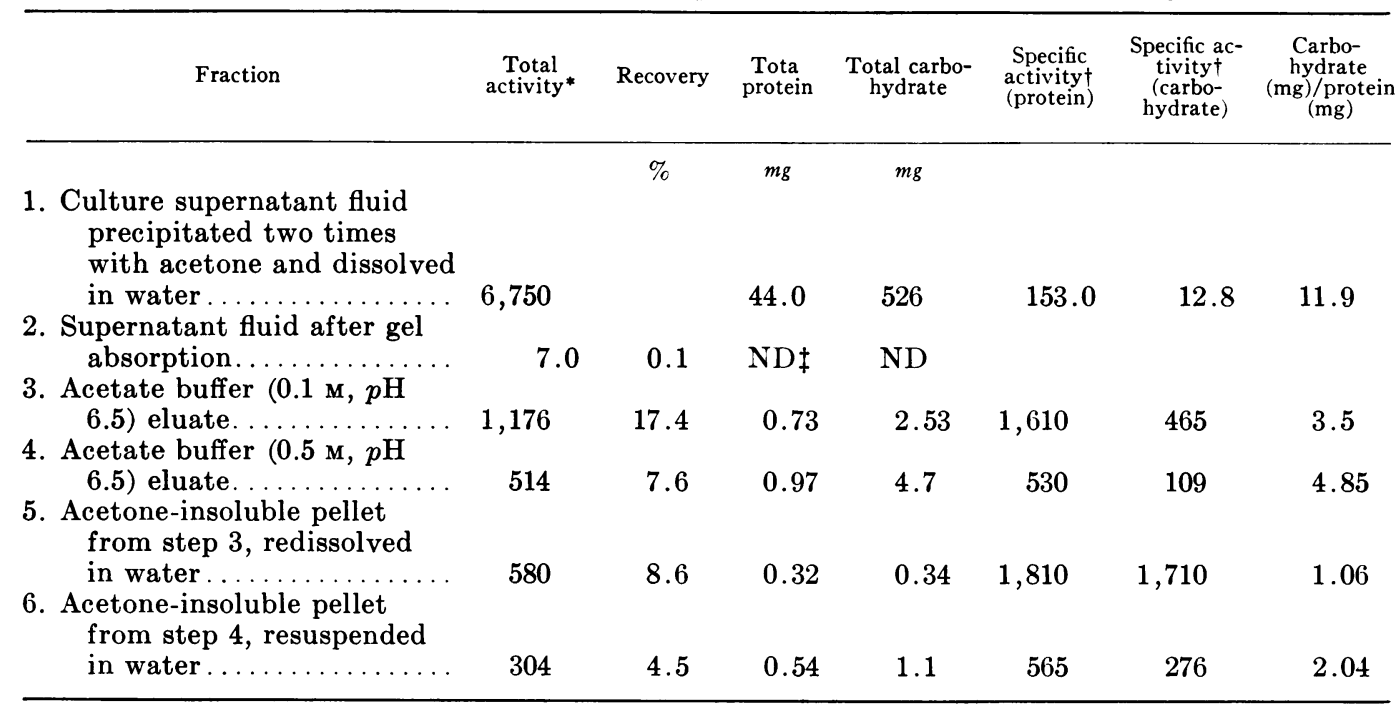

* Expressed as micromoles of $\mathrm{PO}_{4}^{-3}$ per $10 \mathrm{~min}$.

$\dagger$ Expressed as micromoles of $\mathrm{PO}_{4}^{-3}$ per $10 \mathrm{~min}$ per milligram of protein or carbohydrate.

$\ddagger$ Not determined. 
$(15.5 \mathrm{mg} / \mathrm{ml})$ was added to $10 \mathrm{ml}$ of an aqueous solution of the enzyme $(2.1 \mathrm{mg}$ of protein and $28.1 \mathrm{mg}$ of carbohydrate per $\mathrm{ml}$ ). The enzyme was quantitatively adsorbed onto the gel, leaving more than $80 \%$ of the protein and carbohydrate in the supernatant fluid. The gel was washed repeatedly with water and then with $0.01 \mathrm{~m}$ acetate $(p \mathrm{H} 6.5)$, which removed some inactive protein and carbohydrate. Approximately $20 \%$ of the adsorbed enzyme was eluted with $0.1 \mathrm{~m}$ acetate $(p \mathrm{H} \mathrm{6.5)}$. We obtained no further enzyme by continued washing of the gel with this buffer, but another 8 to $10 \%$ of the activity was obtained by treating the gel with $0.5 \mathrm{~m}$ acetate $(p \mathrm{H} 6.5)$. The enzyme fraction eluted with the lower concentration of buffer had a higher specific activity in regard to both protein and carbohydrate. The enzyme was precipitated from these fractions with the addition of 1 volume of cold acetone. At this stage, since the precipitate was flocculent and not gummy, it was collected by centrifugation. The precipitate from the fraction eluted with $0.1 \mathrm{~m}$ acetate dissolved in water; the precipitate from the fraction eluted with $0.5 \mathrm{~m}$ acetate was now water-insoluble. Nevertheless, both fractions were enzymatically active and had high specific activities. There was a 12 -fold purification relative to protein content, and the ratio of carbohydrate to protein on a weight basis dropped to $1: 1$.

\section{Discussion}

In view of the previous report that acid phosphatase is firmly bound to the cell surface of S. mellis (Weimberg and Orton, 1964) and can be dissociated only by physical shearing forces or by enzymatically digesting the cell wall, it was somewhat surprising to discover that the enzyme could be easily extracted from resting cells with $0.5 \mathrm{M} \mathrm{KCl}$ or other ionic compounds without affecting viability too greatly. Furthermore, it is possible to grow $S$. mellis in media containing high salt concentrations and to recover large amounts of enzymatic activity in the culture fluid. Under these latter conditions, the yield of activity may be 10 times greater than that present on resting cells grown in derepressing media to which no $\mathrm{KCl}$ was added. The salt, therefore, is able to remove the enzyme from the cells as the cells are growing, and the organism seems to respond by producing more of this protein. These results suggest that there is a certain "saturating" concentration of acid phosphatase on the cell surface. Under conditions where enzyme synthesis is not repressed, the organism will produce acid phosphatase until this certain concentration is reached. Should conditions be such that this level is not reached, such as by removal of the enzyme with salt, the cell continues to manufacture and excrete the enzyme.

Although salt treatment eluted large amounts of acid phosphatase from resting and growing cells, the dissociation was never quantitative. Always, a small amount of enzyme remained tightly attached to the cells. This residual amount was removed only by digesting the cell wall with snail-gut extract. In addition to this, the recovery of activity in the superantant fluid was greater than that initially present on the cells. The reason for this increase in activity is not apparent from the results presented here. It could be due to an unmasking of more active enzyme as protein is separated from the cells, or it could be due to an alteration in protein structure in the presence of the reagents resulting in increased activity; this will have to be determined in future work.

The fact that ionic compounds are required for enzyme release and that neutral substances cannot replace them indicates that acid phosphatase is held to the cell wall by electrostatic forces. In addition, disulfide bonds seem to be involved in some manner. Thiol alone removes no enzyme from cells, but does stimulate the rate at which enzyme is eluted from resting cells by $\mathrm{KCl}$. In acetone-dried cells, though, the need for a thiol is obligatory. Acid phosphatase is removed from dried cells only in the presence of both salt and thiol or, if cells are treated with these reagents in a stepwise manner, when thiol treatment precedes exposure of the cells to salt. The need to break disulfide bonds before enzymatic activity can be eluted from dehydrated cells is similar to the conditions reported for the extraction of intracellular constituents from $S$. mellis (Weimberg and Orton, 1964). On the other hand, treatment of resting cells with thiol and $2 \mathrm{~m} \mathrm{KCl}$ in a similar stepwise manner does not result in enzyme elution. Although the thiol treatment would break disulfides on the cell surface to sulfhydryl groups, in resting cells it is possible that sulfhydryls are reoxidized back to disulfide by exposure of the cells to air during washing to remove excess reagent. If the disulfide bonds have re-formed, then of course a subsequent treatment with $2 \mathrm{M} \mathrm{KCl}$ would not be able to remove any enzyme.

In this same connection, the function of thiols and salts in protoplast formation and stabilization must be considered. Before the enzyme present in snail-gut extracts can digest cell walls of $S$. meilis, the cells must be treated with a thiol reagent (Weimberg and Orton, 1964). It may be that the component held together by disulfide bridges makes the external surface of the cell impervious to the enzymes in the snail extract so that they cannot reach the sites that 
are their substrates. The thiols would break these bonds, permitting the constituents of the snail extract to penetrate the cell-wall area. Studies on protoplast formation in S. mellis were all done with cells in the maximal stationary phase of growth. It has been the experience of many investigators working with other species of yeasts that protoplasts can be obtained only from cells that are in the log phase of growth (Phaff, 1963; McLellan and Lampen, 1963; Mendoza and Villanueva, 1962; Holter and Ottolenghi, 1960; Eddy and Williamson, 1957). However, there are only two reports of the use of thiols (cysteine) in the system used for protoplast formation or exocellular enzyme release, but the thiol was only stimulatory on the rate of the reaction and not necessary (McLeelan and Lampen, 1963; Burger, Bacon, and Bacon 1961). It may be that thiol is required in the $S$. mellis system because the cells are so old. Recently Duell, Inoue, and Utter (1964) reported that it is possible to obtain protoplasts of $S$. cerevisiae at any stage of the growth cycle, including "old" cells, if the cells are first treated with 2-mercaptoethylamine. The conditions described are very similar to those developed for the $S$. mellis system.

The reason such extremely high concentrations of salt are required to stabilize $S$. mellis protoplasts is not clear. It was also observed that it is only in solutions of ionic compounds that protoplasts can be obtained. Though the cell wall appears to be digested in solutions in which high osmotic pressure is maintained by neutral compounds, the cells will lyse if they are suspended in water. Release of enzymatic activity under these latter conditions appears to be closely related to a general breakdown of cell-wall structure, since acid phosphatase is not found in the soluble fraction until cell lysis begins.

Extraction of resting cells of S. mellis with $\mathrm{KCl}$ and $\beta$-mercaptoethanol removes several constituents from the cell surface. Extracts contain protein and a carbohydrate which is probably a mannan. Both reagents extract approximately the same amount of carbohydrate, but thiol is responsible for the elution of much larger quantities of protein than are extracted by salt. In this connection, nearly twice as much protein is extracted by $0.5 \mathrm{M} \mathrm{KCl}$ as by $2.0 \mathrm{M} \mathrm{KCl}$ in the same length of time. The $0.5 \mathrm{M} \mathrm{KCl}$ extract contains acid phosphatase activity, whereas the higher salt extract does not. These same compounds are found in the culture supernatant fluid of cells grown in media containing $0.25 \mathrm{M}$ $\mathrm{KCl}$. The constituents are present as large macromolecules, as shown by Sephadex gel filtration.
Partial purification of acid phosphatase has been possible, with a 12 -fold increase in specific activity with respect to protein, and a decrease in the carbohydrate-protein ratio from $12: 1$ to $1: 1$ on a basis of weight. This extraction procedure, therefore, can remove from the cell surface large amounts of materials, besides acid phosphatase, which are nonessential for viability.

Chemical composition and structure of the yeast cell wall have been the subject of intensive research in the past few years (for reviews, see Phaff, 1963; Nickerson, 1963). However, there has been no work done on the cell walls of $S$. mellis or any other osmophilic yeast. As far as it is known, the yeast cell wall is composed mainly of two carbohydrate polymers, a glucan and a mannan. There are smaller amounts of other macromolecules, such as lipid and chitin. The glucan seems to be the portion responsible for cell-wall rigidity and shape. The wall appears to be composed of two layers, with the mannan occupying the external layer (Mundkur, 1960). Once the mannan has been dissociated from clean cell-wall preparations by such procedures as boiling in alkali, it is water-soluble and precipitable as a copper salt (Haworth, Hirst, and Isherwood, 1937; Bishop, Blank, and Gardner, 1960). In addition, proteins were also detected in the yeast cell wall (Northcote and Horne, 1952; Kessler and Nickerson, 1959; Falcone and Nickerson, 1956). They were isolated in association with one or another of the carbohydrates in a tightly bound complex. Disulfide linkages in yeast cell walls and their enzymatic reduction were also reported (Nickerson and Falcone, 1956a, b). Sulfhydryl groups seem to be absent from the cell surface (Pomeranz, 1962; Mundkur, 1964). Thus, if the cell wall of $S$. mellis conforms to this description, there is ample support for the concept that the two constituents eluted by $\mathrm{KCl}$ and $\beta$-mercaptoethanol were originally located in the wall region of these cells. Of course, it still is not known how much of the total mannan and protein on the cell surface is extracted by this procedure, or whether any other cell-wall components are eluted.

Recently, Neu and Heppel (1964) described the elution of four enzymes from the cell surface of $E$. coli without impairing viability. The enzymes were dissociated by a "cold water wash" after the cells had been suspended in $20 \%(0.58$ M) sucrose. This action is similar to the release of the "external amino acid pool" in yeast by "osmotic shock" (Cowie and McClure, 1959; Halvorson and Cowie, 1961), the removal of the "competence factor" from Bacillus cereus (Felk- 
ner and Wyss, 1964), the elution of invertase from yeast (Burger et al., 1961), and the removal of the inorganic phosphate and part of the polyphosphate fractions from $S$. mellis after incubation in high concentrations of salt (Weimberg and Orton, 1965). The dissociation of acid phosphatase from $S$. mellis, however, differs from these other systems. Suspending cells of S. mellis in sucrose does not elute any enzyme, and it does not alter the cell surface in such a way that the enzyme may be removed by subsequently washing the cells in water. A high concentration of salt of approximately $2 \mathrm{~m}$ does alter the cell surface, but not sufficiently for acid phosphatase to be eluted with water. The cells still require a further treatment with $\beta$-mercaptoethanol before the enzyme can dissociate. It is interesting, though, that it is possible to remove enzymes from the external surface of two such unrelated organisms as $E$. coli and $S$. mellis by mild techniques that do not destroy viability.

\section{Literature Cited}

Bishop, C. T., F. Blank, and P. E. Gardner. 1960. The cell wall polysaccharides of Candida albicans: glucan, mannan, and chitin. Can. J. Biochem. 38:869-881.

Burger, M., E. E. BACon, AND J. S. D. BACoN. 1961. Some observations on the form and location of invertase in the yeast cell. Biochem. $J$. 78:504-511.

Cifonelli, J. A., And F. Smith. 1955. The polysaccharide associated with yeast invertase. J. Am. Chem. Soc. 77:5682-5684.

Cowie, D. B., And F. T. McClure. 1959. Metabolic pools and the synthesis of macromolecules. Biochim. Biophys. Acta 31:236-245.

Duell, E. A., S. Inoue, ANd M. F. Utter. 1964. Isolation and properties of intact mitochondria from spheroplasts of yeasts. J. Bacteriol. 88:1762-1773.

Eddy, A. A., and D. H. Williamson. 1957. A method of isolating protoplasts from yeast. Nature 179:1252-1253.

Falcone, G., and W. J. Nickerson. 1956. Cellwall mannan-protein of baker's yeast. Science 124:272-273.

Felkner, I. C., and O. Wyss. 1964. A substance produced by competent Bacillus cereus 569 cells that affects transformability. Biochem. Biophys. Res. Commun. 16:94-99.

Halvorson, H. O., ANd D. B. Cowie. 1961. Metabolic pools of amino acids and protein synthesis in yeast, p. 479-487. In A. Kleinzeller and A. Kotyk [ed.], Membrane transport and metabolism. Academic Press, Inc., New York.

Hassid, W. Z., and S. Abraham. 1957. Chemical procedures for analysis of polysaccharides, $p$.
34-50. In S. P. Colowick and N. O. Kaplan [ed.], Methods in enzymology, vol. 3. Academic Press, Inc., New York.

Haworth, W. N., E. L. Hirst, AND F. A. Isherwood. 1937. Polysaccharides. XXIV. Yeast mannan. J. Chem. Soc., p. 784-791.

Holter, H., AND P. OtTolenghi. 1960. Observations on yeast protoplasts. Compt. Rend. Trav. Lab. Carlsberg 31:409-422.

Keilin, D., ANd E. F. Hartree. 1938. Mechanism of the decomposition of hydrogen peroxide by catalase. Proc. Roy. Soc. (London) Ser. B 124:397-405.

Kessler, G., and W. J. Nickerson. 1959. Glucomannan-protein complexes from cell walls of yeasts. J. Biol. Chem. 234:2281-2285.

Lowry, O. H., N. J. Rosebrough, A. L. FarR, AND R. J. RANDALl. 1951. Protein measurement with the Folin phenol reagent. J. Biol. Chem. 193:265-275.

McLellan, W. L., JR., and J. O. Lampen. 1963. The acid phosphatase of yeast. Localization and secretion by protoplasts. Biochim. Biophys. Acta 67:324-326.

Mendoza, C. G., and J. R. Villanueva. 1962. Production of yeast protoplasts by an enzyme preparation of Streptomyces sp. Nature 195: 1326-1327.

MundKuR, B. 1960. Electron-microscopical studies of frozen-dried yeast. I. Localization of polysaccharides. Exptl. Cell Res. 20:28-42.

MUNDKUR, B. 1964. Electron-microscopical studies of frozen-dried yeast. V. Localization of protein-bound sulfhydryl. Exptl. Cell Res. 34:155181.

Neu, H. C., ANd L. A. Heppel. 1964. On the surface localization of enzymes in $E$. coli. Biochem. Biophys. Res. Commun. 17:215-219.

Nickerson, W. J. 1963. Symposium on biochemical bases of morphogenesis in fungi. IV. Molecular bases of form in yeasts. Bacteriol. Rev. 27:305-324.

Nickerson, W. J., and G. Falcone. 1956a. Enzymatic reduction of disulfide bonds in cell wall protein of baker's yeast. Science 124:318319.

Nickerson, W. J., and G. Falcone. $1956 b$. Identification of protein disulfide reductase as a cellular division enzyme in yeasts. Science 124:722-723.

Northcote, D. H., and R. W. Horne. 1952. The chemical composition and structure of the yeast cell wall. Biochem. J. 51:232-236.

Phaff, H. J. 1963. Cell wall of yeasts. Ann. Rev. Microbiol. 17:15-30.

Pomeranz, Y. 1962. Distribution of proteinbound sulfhydryl groups in yeast cells. J. Histochem. Cytochem. 10:568-571.

Svihla, G., F. Schlenk, and J. L. Dainko. 1961. Spheroplasts of the yeast Candida utilis. J. Bacteriol. 82:808-814.

Taussky, H. A., ANd E. Shorr. 1953. A micro- 
colorimetric method for the determination of inorganic phosphorus. J. Biol. Chem. 202:675685.

Weimberg, R., and W. L. Orton. 1963. Repressible acid phosphomonoesterase and constitutive pyrophosphatase of Saccharomyces mellis. J. Bacteriol. 86:805-813.

Weimberg, R., and W. L. Orton. 1964. Evi- dence for an exocellular site for the acid phosphatase of Saccharomyces mellis. J. Bacteriol. 88:1743-1754.

Weimberg, R., and W. L. Orton. 1965. Synthesis and breakdown of the polyphosphate fraction and acid phosphomonoesterase of Saccharomyces mellis and their locations in the cell. J. Bacteriol. 89:740-747. 